\title{
Comparison of Religious Identity Politics Reporting on Depok Muamalah Market
}

\author{
Tabah Maryanah \\ Department of Government Sciences \\ Lampung University \\ Lampung, Indonesia \\ tabah.maryanah@fisip.unila.ac.id
}

\author{
Lilih Muflihah \\ Department of Government Sciences \\ Lampung University \\ Lampung, Indonesia \\ lilih.muflihah@ fisip.unila.ac.id
}

\begin{abstract}
The press is one of the important pillars of democracy. News coverage by the press, both print media and online media as well as television has also colored the democratic process. Moreover, news related to the issue of identity. This article is about how Republika.co.id and Kompas.com frame the Depok Muamalah Market through the news. The news is related to the ideology adopted by the media. The media is an arena for ideological contestation. Data was collected through news documentation about the Depok Muamalah Market made by Republika.co.id and Kompas.com. Data were analyzed using Robert M. Entman's framing analysis. The results show that the framing in the coverage of the Depok Muamalah Market is related to the ideology of the press. Kompas.com tends to frame the coverage of the Depok Muamalah Market with a political identity, namely Indonesian nationalism. This is in line with the ideology adopted by Kompas.com, namely nationalism. Meanwhile, Republika.co.id in its coverage of the Depok Muamalah Market tends to use a political frame of religious identity, namely Islam, in line with Republika.co.id's ideology, namely Islam. Both of them still maintain the ideology that has been promoted since the establishment of the news media institution. In a democracy, the difference in framing that will create discourse and social reality is a natural thing and is an indication that democracy works because there is freedom of opinion in the public sphere.
\end{abstract}

Keywords-Religious Identity Politics, Political communication, Democracy, Islam, Muamalah Market

\section{INTRODUCTION}

The press is one of the important pillars of democracy. News coverage by the press, both print media and online media, as well as television, has also colored the democratic process. Moreover, news related to the issue of identity. The issue of identity is very sensitive, as Indonesian society has been divided since the 2014 election. The backwardness of Indonesian society is increasingly sharpened by the 2017 Jakarta Election and the 2014 Presidential Election. Issues of religious identity, ethnicity, and sexual orientation are becoming increasingly frequently reported.

One of the religious identity issues that were widely reported in early 2021 was the Depok Muamalah Market. Based on its name, Pasar Muamalah Depok, which is located on Jalan Raya Baru, Beji, Depok, West Java, is associated with the religion with the most adherents in Indonesia, namely Islam. Moreover, in Muamalah Market, Depok, dirhams, and dinars circulated. The names dirham and dinar are also associated with Islam because they are the names of the currencies used by Arab countries in the Middle East region. Arabia is the center and mecca of Muslims.

Although the issue of the Depok Muamalah Market briefly surfaced in early 2021 , not all national mass media reported it. For example, The Jakarta Post online. None of the news appeared using a search engine with the keyword muamalah on the thejakartapost.com site. Meanwhile, mediaindonesia.com, jawapos.com, tempo.com and cnn.com make quite a lot of news about the Depok Muamalah Market. Republika.co.id mostly displays news about Depok Muamalah Market. Even since 2016, before the Depok Muamalah Market became an issue that attracted a lot of public interest as happened in early 2021. Kompas.com also reports quite a lot about the Depok Muamalah Market and in a different tone from Republika.co.id. Therefore, these two online media will be researched and compared. Both were also chosen because they are easily accessible and have more readers compared to print media.

Based on this background, the question of this research is how do Kompas.com and Republika.co.id frame the Depok Muamalah Market? Is the framing influenced by ideology, media economic interests, or something else? 


\section{THEORETICAL FRAMEWORK}

\section{A. The Politics of Identity}

Identity politics is politics based on group identity and is the opposite of interests, reforms, or ideologies [1]. This means that political activity is aimed at group interests, not for individual interests alone. Human identity is very diverse, both based on social identity, politics, and cultural discourse [2]. Therefore, the manifestation of identity politics is also very diverse. Social-based identity will manifest in class, race, ethnicity, gender, religion, and sexuality. Identity-based politics in the form of nationalism and citizenship. Meanwhile, discourse-based identity consists of socialists, communists, liberals, republicans, fundamentalists, radicals, terrorists, and many others.

\section{B. Press, Democracy, and Politics of Identity}

The press is an important element of democracy. The press is agreed upon as the fourth pillar of democracy (the fourth estate), in addition to the legislature, executive, judiciary, along with other state institutions and civil society. The press, through its reporting, will be able to control other elements of democracy and even be able to create certain discourses and create reality. To create reality, the press uses three elements, namely: (1) the use of political symbols (the language of politics), (2) message packaging strategies (framing strategies), and (3) the willingness of the media to provide a place (agenda-setting function) in the media. news coverage [3-5]. Whereas in the democratic process, the press has at least five functions, namely surveillance, education, platform, publicity, and advocacy [6]. The function of surveillance is to provide citizens with information about what is happening around them. The function of education is to teach the meaning of the facts that occur. The function of providing a platform is to provide or shape public political discourse and facilitate the formation of public opinion, including different public opinions. The function of publicity is to proclaim as well as a watchdog on the work of political and government institutions. The function of advocacy on the political views of the community through the principle of openness.

Democracy is also understood in terms of freedom of speech, expression, and association [7]. In this sense, every citizen has the right to express opinions, express thoughts, feelings, and desires. Every citizen also has the right to form or join certain communities and organizations. Freedom also includes expressing one's identity, whether it is based on social, political, or cultural discourse.

Related to group identity, fair democracy applies three principles, namely: civic equality, equal freedom, and basic opportunity [8]. Civic equality is the obligation to treat all individuals as equal agents in democratic politics and support the conditions that are necessary for their equal treatment as citizens. Equal freedom is the obligation of democratic government to respect the liberty of all individuals to live their own lives as they see fit consistent with the equal liberty of others. Basic opportunity is the capacity of individuals to live a decent life with a fair chance to choose among their preferred ways of life. Nevertheless, assessing the relationship between identity groups and democratic politics in this case used civic equality as a principled basis.

Public expressions, including expressions of religious identity, are often reported by the mass media or the press. Reporting by the media is not always what it is. Reporting by the press is colored by the identity or ideology of the media and the people who manage the media. As stated earlier that ideology, political attitudes, editorial policies of a media also determine the use of political symbols, message packaging, and giving place to an issue or political power in the news. This will result in a certain expression of identity which will lead to different public opinions, depending on how the media report it. The way the media reports on an event is not only influenced by ideology, political attitudes, and editorial policies, the media coverage is also influenced by the economic interests of the media as industrial institutions. Sometimes it is even controlled by state power. Therefore, the press has become a media as well as an arena for contesting various interests and powers [9].

\section{METHOD}

This research is qualitative. Data collection was carried out using documentation techniques, namely collecting news about the Depok Muamalah Market published by Kompas.com and Republika.co.id. The data are analyzed using framing analysis. Framing analysis seeks to understand (verstehen) and interpret the meaning of a text by outlining how the media frame an issue [10]. The framing analysis chosen is the Robert M. Entman model [10]. The Entman model was chosen because it is simple, involving only two aspects and four steps. The Entman model is used because it is relevant to the theory in this study. Entman's model is also the most adequate for understanding the media's framing of religious identity politics, especially regarding the Depok Muamalah Market, which will be related to one religion and is the religion with the most adherents in Indonesia.

There are two aspects in Entman's model framing analysis, namely the selection of issues and the highlighting of certain aspects of the issue. The aspect of issue selection is related to the inclusion and exclusion of facts that will be reported. Not all facts are reported by the online media. It is the media manager who decides. Highlighting certain aspects of issues related to writing facts through the use of sentences, pictures, and images in the news. While the framing steps of the Entman model there are four, namely: (1) defining the problem, namely how an issue is seen, treated as what, or as what problem. (2) estimating the 
problem or source of the problem, i.e. the event caused by what, what caused it, who caused the problem. (3) make a moral judgment or evaluation, namely what ideology is used to explain the problem and legitimize or delegitimize the action. (4) Recommendations, namely what solutions are offered to overcome the problem.

\section{RESULT}

\section{A. Kompas.com's frame about Muamalah Market Depok}

Kompas.com is part of PT Gramedia Kompas which has been operating since 1965. Kompas.com itself was only published in 1995 and since August 6, 1998, has been a separate business unit under the management of PT Kompas Cyber Media (KCM) (https://inside.kompas .com/about-us). Although it is a separate business unit from PT Gramedia Kompas, ideologically it is no different from its parent company, namely nationalism.

Kompas.com has reported on the Depok Muamalah Market from January 28, 2021, to February 9, 2021. In a digital era that is very mobile and considering that there are so many important and interesting events in society, an abundance of issues can be covered. The Depok Muamalah Market was reported by Kompas.com with a fairly long duration, namely 12 days and a fairly frequent frequency, namely 23 times, as shown in Table 1 .

\section{1) Problem identification.}

Kompas.com identified the Depok Muamalah Market as an issue of nationalism. Nationalism in this context is the enforcement of laws and regulations regarding money to maintain the sovereignty of the rupiah in the territory of the Republic of Indonesia. As stated in Table 1, the news about the Depok Muamalah Market tends to be highlighted by Kompas.com using the perspective of nationalism with the notion of law enforcement for rupiah sovereignty. Depok Muamalah Market is not seen as an economic issue or an issue of religious identity.

There are two reasons to judge that the dominant frame used by Kompas.com is law enforcement. First, almost all reporting is related to the law. The second reason that the dominant frame used by Kompas.com is law enforcement. The dominant news sources interviewed are the police and the government, in this case, the Head of Tanah Baru, Beji, Depok, West Java. Even if there are other sources such as the chairman of the MUI and traders at the Muamalah Market in Depok, they are unable to compete with legal discourse from news sources from the police and the government. The main news sources tend to look at the legal aspects, namely market licensing and violations of laws and criminal sanctions.
TABLE I. NEWS ABOUT MUAMALAH MARKET OF DEPOK BY KOMPAS.COM

\begin{tabular}{|c|c|c|}
\hline Title of News & Content of News & Source of News \\
\hline $\begin{array}{l}\text { Viral News } \\
\text { Muamalah } \\
\text { Market in } \\
\text { Depok } \\
\text { Transaction } \\
\text { Using Dirham } \\
\text { and Dinar, This } \\
\text { Explanation } \\
\text { Lurah Video } \\
\text { Kompas TV } \\
\text { about } \\
\text { transactions } \\
\text { using dirhams } \\
\text { and offices in } \\
\text { Depok [11] }\end{array}$ & $\begin{array}{l}\text { Interview with Zakky } \\
\text { Fauzan that the } \\
\text { transaction of buying } \\
\text { and selling in the } \\
\text { market does not use } \\
\text { rupiah but uses dinar } \\
\text { and dirham coins. }\end{array}$ & $\begin{array}{l}\text { Zakky Fauzan } \\
\text { (Subdistrict head, } \\
\text { called Lurah, } \\
\text { Tanah Baru) }\end{array}$ \\
\hline $\begin{array}{l}\text { Muamalah } \\
\text { Market in } \\
\text { Depok That } \\
\text { Accepts Dinar } \\
\text { and Dirham } \\
\text { Transactions } \\
\text { Does Not Have } \\
\text { Permission } \\
\text { Kompas TV } \\
\text { Video Video } \\
\text { about dirham } \\
\text { and service } \\
\text { transactions in } \\
\text { Depok [12] }\end{array}$ & $\begin{array}{l}\text { Interview with Zakky } \\
\text { Fauzan That } \\
\text { Muamalah Market of } \\
\text { Depok is not licensed } \\
\text { and unknown to its } \\
\text { activities by local } \\
\text { environmental and } \\
\text { village administrators. }\end{array}$ & $\begin{array}{l}\text { Zakky Fauzan } \\
\text { (Lurah Tanah } \\
\text { Baru) }\end{array}$ \\
\hline $\begin{array}{l}\text { Viral } \\
\text { Transactions } \\
\text { Using Dinar and } \\
\text { Dirham, BI: } \\
\text { Only Valid } \\
\text { Rupiah Payment } \\
\text { Instruments in } \\
\text { NKRI! [13] }\end{array}$ & $\begin{array}{l}\text { Press release of the } \\
\text { Executive Director, } \\
\text { Head of The } \\
\text { Communication } \\
\text { Department of Bank } \\
\text { Indonesia (BI) that the } \\
\text { rupiah is the only legal } \\
\text { means of payment in } \\
\text { the Unitary State of } \\
\text { the Republic of } \\
\text { Indonesia. Dinars, } \\
\text { dirhams, or other } \\
\text { forms other than } \\
\text { rupiah are not legal } \\
\text { means of payment. }\end{array}$ & $\begin{array}{l}\text { Erwin Haryono } \\
\text { (Executive } \\
\text { Director, Head of } \\
\text { Bank Indonesia } \\
\text { Communications } \\
\text { Department) }\end{array}$ \\
\hline $\begin{array}{l}\text { Viral } \\
\text { Transactions } \\
\text { Using Dinars } \\
\text { and Dirhams in } \\
\text { Depok, } \\
\text { Explanation of } \\
\text { Lurah and } \\
\text { Potential } \\
\text { Violation of } \\
\text { The Law [14] }\end{array}$ & $\begin{array}{l}\text { Based on an interview } \\
\text { with Zakky Fauzan } \\
\text { Kompas.com raised } \\
\text { the news that } \\
\text { Muamalah Market of } \\
\text { Depok has the } \\
\text { potential to violate the } \\
\text { law. Based on } \\
\text { applicable regulations, } \\
\text { parties who use } \\
\text { currencies other than } \\
\text { Rupiah in transacting } \\
\text { in Indonesia will be } \\
\text { subject to criminal } \\
\text { sanctions. }\end{array}$ & $\begin{array}{l}\text { Zakky Fauzan } \\
\text { (Lurah Tanah } \\
\text { Baru) }\end{array}$ \\
\hline $\begin{array}{l}\text { Viral News Of } \\
\text { Transactions } \\
\text { Using Dinar and } \\
\text { Dirham in } \\
\text { Depok, What } \\
\text { Are the } \\
\text { Sanctions? } \\
\text { Kompas TV } \\
\text { video on BI }\end{array}$ & $\begin{array}{l}\text { Not using rupiah in } \\
\text { transactions that have } \\
\text { payment purposes can } \\
\text { be criminally charged. } \\
\text { The criminals include } \\
\text { a maximum prison } \\
\text { term of one year and a } \\
\text { maximum fine of Rp } \\
200 \text { million. }\end{array}$ & $\begin{array}{l}\text { Erwin Haryono } \\
\text { (Executive } \\
\text { Director, Head of } \\
\text { BI } \\
\text { Communications } \\
\text { Department) }\end{array}$ \\
\hline
\end{tabular}




\begin{tabular}{|c|c|c|}
\hline $\begin{array}{l}\text { rules regarding } \\
\text { money [15] }\end{array}$ & & \\
\hline $\begin{array}{l}\text { Viral } \\
\text { Transactions } \\
\text { Using Dinars } \\
\text { and Dirhams in } \\
\text { Depok, } \\
\text { Explanation of } \\
\text { Lurah and } \\
\text { Potential } \\
\text { Violation of } \\
\text { The Law [16] }\end{array}$ & $\begin{array}{l}\text { Based on an interview } \\
\text { with Zakky Fauzan } \\
\text { Kompas.com raised } \\
\text { the news that } \\
\text { Muamalah Market of } \\
\text { Depok has the } \\
\text { potential to violate the } \\
\text { law. Based on } \\
\text { applicable regulations, } \\
\text { parties who use } \\
\text { currencies other than } \\
\text { Rupiah in transacting } \\
\text { in Indonesia will be } \\
\text { subject to criminal } \\
\text { sanctions. }\end{array}$ & $\begin{array}{l}\text { Zakky Fauzan } \\
\text { (Lurah Tanah } \\
\text { Baru) }\end{array}$ \\
\hline $\begin{array}{l}\text { Viral News Of } \\
\text { Transactions } \\
\text { Using Dinar and } \\
\text { Dirham in } \\
\text { Depok, What } \\
\text { Are the } \\
\text { Sanctions? } \\
\text { Kompas TV } \\
\text { video on BI } \\
\text { rules regarding } \\
\text { money [17] }\end{array}$ & $\begin{array}{l}\text { Not using rupiah in } \\
\text { transactions that have } \\
\text { payment purposes can } \\
\text { be criminally charged. } \\
\text { The criminals include } \\
\text { a maximum prison } \\
\text { term of one year and a } \\
\text { maximum fine of Rp } \\
200 \text { million. }\end{array}$ & $\begin{array}{l}\text { Chapter X Article } \\
33 \text { point } 1 \text { a of } \\
\text { Law No. } 7 \text { of } \\
2011 \text { on } \\
\text { Currency }\end{array}$ \\
\hline $\begin{array}{l}\text { Traders Said, In } \\
\text { addition to } \\
\text { Dinar and } \\
\text { Dirham Coins, } \\
\text { Muamalah } \\
\text { Market of } \\
\text { Depok Receives } \\
\text { Rupiah and } \\
\text { Barter Video } \\
\text { Video Kompas } \\
\text { TV about the } \\
\text { founder of } \\
\text { Muamalah } \\
\text { Market of } \\
\text { Depok arrested } \\
\text { by police [18] }\end{array}$ & $\begin{array}{l}\text { Interview to Anto that } \\
\text { in addition to dinar } \\
\text { coins and dirham } \\
\text { Pasar Muamalah } \\
\text { Depok received rupiah } \\
\text { and barter. A press } \\
\text { release from Bank } \\
\text { Indonesia that due to } \\
\text { indications of the use } \\
\text { of payment } \\
\text { instruments other than } \\
\text { rupiah in the } \\
\text { community, BI } \\
\text { confirmed that the } \\
\text { rupiah is the only legal } \\
\text { means of payment. }\end{array}$ & $\begin{array}{l}\text { Anto (Muamalah } \\
\text { Market of Depok } \\
\text { trader) Erwin } \\
\text { Haryono } \\
\text { (Executive } \\
\text { Director, Head of } \\
\text { BI } \\
\text { Communications } \\
\text { Department) }\end{array}$ \\
\hline $\begin{array}{l}\text { Viral } \\
\text { Transaction } \\
\text { Using Dinar- } \\
\text { Dirham in } \\
\text { Muamalah } \\
\text { Market of } \\
\text { Depok and } \\
\text { Kompas TV } \\
\text { Video Authority } \\
\text { Response about } \\
\text { the founder of } \\
\text { Pasar } \\
\text { Muamalah } \\
\text { Depok arrested } \\
\text { by police [19] }\end{array}$ & $\begin{array}{l}\text { BI invites the public } \\
\text { and various parties to } \\
\text { maintain the } \\
\text { sovereignty of the } \\
\text { rupiah as a currency. }\end{array}$ & $\begin{array}{l}\text { Erwin Haryono } \\
\text { (Executive } \\
\text { Director, Head of } \\
\text { BI } \\
\text { Communications } \\
\text { Department) }\end{array}$ \\
\hline $\begin{array}{l}\text { It turns out that } \\
\text { Dinar and } \\
\text { Dirham Were } \\
\text { Once in } \\
\text { Muamalah } \\
\text { Cipondoh } \\
\text { Market, This Is } \\
\text { the Story of the } \\
\text { Coordinator } \\
\text { Video of the } \\
\text { founder of Pasar } \\
\text { Muamalah }\end{array}$ & $\begin{array}{l}\text { Interview with Ivan } \\
\text { that Pasar Muamalah } \\
\text { which uses dinars and } \\
\text { dirhams has also been } \\
\text { in Cipondoh, } \\
\text { Tangerang Banten but } \\
\text { has closed in } 2019 \text {. }\end{array}$ & $\begin{array}{l}\text { Ivan (Market } \\
\text { Coordinator } \\
\text { Muamalah } \\
\text { Cipondoh) }\end{array}$ \\
\hline
\end{tabular}

\begin{tabular}{|c|c|c|}
\hline $\begin{array}{l}\text { Depok arrested } \\
\text { by the police } \\
\text { [20] }\end{array}$ & & \\
\hline $\begin{array}{l}\text { Bareskrim } \\
\text { Police Arrest } \\
\text { Muamalah } \\
\text { Market of } \\
\text { Depok Founder } \\
\text { Zaim Saidi } \\
\text { Kompas TV } \\
\text { Video video } \\
\text { about } \\
\text { Muamalah } \\
\text { Market of } \\
\text { Depok founder } \\
\text { arrested by } \\
\text { police [21] }\end{array}$ & $\begin{array}{l}\text { Interview with Brig. } \\
\text { Gen. Rusdi Hartono } \\
\text { that the Criminal } \\
\text { Investigation Agency } \\
\text { (Bareskrim) Police } \\
\text { arrested the founder of } \\
\text { muamalah market in } \\
\text { Depok, Zaim Saidi }\end{array}$ & $\begin{array}{l}\text { Brig. Gen. Rusdi } \\
\text { Hartono (Head of } \\
\text { Public } \\
\text { Information } \\
\text { Bureau of Public } \\
\text { Relations) }\end{array}$ \\
\hline $\begin{array}{l}\text { Arrested by } \\
\text { Police, Founder } \\
\text { of Muamalah } \\
\text { Market of } \\
\text { Depok Zaim } \\
\text { Saidi Status } \\
\text { Suspect Video } \\
\text { founder of Pasar } \\
\text { Muamalah } \\
\text { Depok arrested } \\
\text { by police [22] }\end{array}$ & $\begin{array}{l}\text { Interview with Brig. } \\
\text { Gen. Rusdi Hartono } \\
\text { that Bareskrim Polri } \\
\text { established Muamalah } \\
\text { Market of Depok } \\
\text { founder Zaim Saidi as } \\
\text { a suspect. }\end{array}$ & $\begin{array}{l}\text { Brig. Gen. Rusdi } \\
\text { Hartono (Head of } \\
\text { Public } \\
\text { Information } \\
\text { Bureau of Public } \\
\text { Relations) }\end{array}$ \\
\hline $\begin{array}{l}\text { Police Arrest } \\
\text { Muamalah } \\
\text { Market of } \\
\text { Depok Founder } \\
\text { who Introduced } \\
\text { Dirham and } \\
\text { Dinar as a } \\
\text { Medium of } \\
\text { Exchange Video } \\
\text { Kompas TV } \\
\text { about the } \\
\text { founder of Pasar } \\
\text { Muamalah } \\
\text { Depok arrested } \\
\text { by police [23] }\end{array}$ & $\begin{array}{l}\text { Interview with } \\
\text { Brigadier General } \\
\text { Rusdi Hartono that the } \\
\text { Criminal Investigation } \\
\text { Agency (Bareskrim) } \\
\text { Police arrested the } \\
\text { founder of the } \\
\text { Muamalah Market } \\
\text { network, Zaim Saidi, } \\
\text { who introduced dinars } \\
\text { and dirhams as a } \\
\text { medium of exchange. }\end{array}$ & $\begin{array}{l}\text { Brig. Gen. Rusdi } \\
\text { Hartono (Head of } \\
\text { Public } \\
\text { Information } \\
\text { Bureau of Public } \\
\text { Relations) }\end{array}$ \\
\hline $\begin{array}{l}\text { Alleged } \\
\text { Violation of } \\
\text { Currency Law } \\
\text { in Muamalah } \\
\text { Market of } \\
\text { Depok Case } \\
\text { [24] }\end{array}$ & $\begin{array}{l}\text { The use of dinars and } \\
\text { dirhams violates the } \\
\text { Currency Law because } \\
\text { it does not use rupiah. }\end{array}$ & $\begin{array}{l}\text { Chapter X Article } \\
33 \text { point 1a of } \\
\text { Law No. } 7 \text { of } \\
2011 \text { on } \\
\text { Currency }\end{array}$ \\
\hline $\begin{array}{l}\text { Suspect, } \\
\text { Muamalah } \\
\text { Market Founder } \\
\text { Zaim Saidi } \\
\text { Threatened with } \\
1 \text { Year in Prison } \\
\text { Kompas TV } \\
\text { Video about } \\
\text { Zaim Saidi } \\
\text { threatened with } \\
\text { a maximum of } \\
15 \text { years in } \\
\text { prison [25] }\end{array}$ & $\begin{array}{l}\text { The police press } \\
\text { conference that based } \\
\text { on Article } 9 \text { of Law } \\
\text { No. } 1 \text { of } 1946 \text { on } \\
\text { Criminal Law and } \\
\text { Article } 33 \text { of Law No. } \\
7 \text { of } 2011 \text { on Currency } \\
\text { threatened a penalty of } \\
1 \text { year in prison and a } \\
\text { fine of } 200 \text { million } \\
\text { rupiahs for Zaim } \\
\text { Saidi. }\end{array}$ & $\begin{array}{l}\text { Kombes (Pol) } \\
\text { Ahmad } \\
\text { Ramadhan (Head } \\
\text { of Public } \\
\text { Information } \\
\text { Division of } \\
\text { Public Relations } \\
\text { Division of } \\
\text { Police) }\end{array}$ \\
\hline $\begin{array}{l}\text { Mabes Polri: } \\
\text { Muamalah } \\
\text { Market of } \\
\text { Depok Has } \\
\text { Been Operating } \\
\text { Since } 2014 \text { [26] }\end{array}$ & $\begin{array}{l}\text { Polri press conference } \\
\text { that muamalah market } \\
\text { in Tanah Baru, Depok, } \\
\text { West Java has been } \\
\text { operating since } 2014 \text {. }\end{array}$ & $\begin{array}{l}\text { Kombes (Pol) } \\
\text { Ahmad } \\
\text { Ramadhan (Head } \\
\text { of Public } \\
\text { Information } \\
\text { Division of } \\
\text { Public Relations }\end{array}$ \\
\hline
\end{tabular}




\begin{tabular}{|c|c|c|}
\hline & & $\begin{array}{l}\text { Division of } \\
\text { Police) }\end{array}$ \\
\hline $\begin{array}{l}\text { Chronology of } \\
\text { Zaim Saidi } \\
\text { Arrest, Starting } \\
\text { from Dinar- } \\
\text { Dirham } \\
\text { Transaction in } \\
\text { Muamalah } \\
\text { Market [27] }\end{array}$ & $\begin{array}{l}\text { At first, there was a lot } \\
\text { of talk about the } \\
\text { internet on social } \\
\text { media. The market is } \\
\text { known not to accept } \\
\text { transactions using } \\
\text { rupiah but uses dinar } \\
\text { and dirham coins. } \\
\text { Zaim Saidi was } \\
\text { arrested by Bareskrim } \\
\text { Police. }\end{array}$ & $\begin{array}{l}\text { Social media. } \\
\text { Zakky Fauzan } \\
\text { (Lurah Tanah } \\
\text { Baru) Brig. Gen. } \\
\text { Rusdi Hartono } \\
\text { (Head of Public } \\
\text { Information } \\
\text { Bureau of Public } \\
\text { Relations Of } \\
\text { Police) }\end{array}$ \\
\hline $\begin{array}{l}\text { This is the } \\
\text { Criminal Article } \\
\text { that Snares } \\
\text { Zaim Saidi, } \\
\text { Founder of } \\
\text { Muamalah } \\
\text { Market of } \\
\text { Depok [28] }\end{array}$ & $\begin{array}{l}\text { The police press } \\
\text { conference that based } \\
\text { on Article } 9 \text { of Law } \\
\text { No. } 1 \text { of } 1946 \text { on } \\
\text { Criminal Law and } \\
\text { Article } 33 \text { of Law No. } \\
7 \text { of } 2011 \text { on Currency } \\
\text { threatened a penalty of } \\
1 \text { year in prison and a } \\
\text { fine of } 200 \text { million } \\
\text { rupiahs for Zaim } \\
\text { Saidi. }\end{array}$ & $\begin{array}{l}\text { Kombes (Pol) } \\
\text { Ahmad } \\
\text { Ramadhan (Head } \\
\text { of Public } \\
\text { Information } \\
\text { Division of } \\
\text { Public Relations } \\
\text { Division of } \\
\text { Police) }\end{array}$ \\
\hline $\begin{array}{l}\text { Facts of Arrest } \\
\text { zaim Saidi, } \\
\text { Founder of } \\
\text { Pasar } \\
\text { Muamalah } \\
\text { Depok Video } \\
\text { Video Kompas } \\
\text { TV video about } \\
\text { Zaim Saidi } \\
\text { threatened with } \\
1 \text { year in prison } \\
\text { [29] }\end{array}$ & $\begin{array}{l}\text { Summary of news } \\
\text { about the arrest of } \\
\text { Zaim Saidi, Founder } \\
\text { of Muamalah Market } \\
\text { of Depok }\end{array}$ & $\begin{array}{l}\text { Kombes (Pol) } \\
\text { Ahmad } \\
\text { Ramadhan (Head } \\
\text { of Public } \\
\text { Information } \\
\text { Division of } \\
\text { Public Relations } \\
\text { Division of } \\
\text { Police) }\end{array}$ \\
\hline $\begin{array}{l}\text { The transaction } \\
\text { with Dirham, } \\
\text { Price of } 2 \mathrm{Kg} \text { of } \\
\text { Eggs Equivalent } \\
\text { to Rp } 73,500 \text { in } \\
\text { Muamalah } \\
\text { Market of } \\
\text { Depok Video } \\
\text { Video Kompas } \\
\text { TV about more } \\
\text { expensive } \\
\text { commodity } \\
\text { prices, it is } \\
\text { difficult to be } \\
\text { able to return } \\
\text { [30] }\end{array}$ & $\begin{array}{l}\text { Kompas TV interview } \\
\text { with Sari, a trader in } \\
\text { Pasar Muamalah } \\
\text { Depok, that because } \\
\text { transactions use } \\
\text { dirhams, commodity } \\
\text { prices become more } \\
\text { expensive. }\end{array}$ & $\begin{array}{l}\text { "Aiman" } \\
\text { Programme } \\
\text { Kompas TV }\end{array}$ \\
\hline $\begin{array}{l}\text { Zaim Saidi } \\
\text { Detained by } \\
\text { Police in } \\
\text { Muamalah } \\
\text { Market Case in } \\
\text { Depok, This Is } \\
\text { Why [31] }\end{array}$ & $\begin{array}{l}\text { The interview with } \\
\text { Kombes Ahmad } \\
\text { Ramadhan that the } \\
\text { reason the police } \\
\text { detained Zaim Saidi, } \\
\text { the brains behind the } \\
\text { muamalah market } \\
\text { network that accepts } \\
\text { dinar and dirham coin } \\
\text { transactions, is } \\
\text { because it has fulfilled } \\
\text { the elements of } \\
\text { criminal acts. }\end{array}$ & $\begin{array}{l}\text { "Aiman" } \\
\text { Programme } \\
\text { Kompas TV }\end{array}$ \\
\hline $\begin{array}{l}\text { Dinar-Dirham } \\
\text { coins in } \\
\text { Muamalah } \\
\text { Market of } \\
\text { Depok Called }\end{array}$ & $\begin{array}{l}\text { Kompas TV interview } \\
\text { with Sari, a trader at } \\
\text { Pasar Muamalah } \\
\text { Depok, that the dinar- } \\
\text { dirham coin produced }\end{array}$ & $\begin{array}{l}\text { "Aiman" } \\
\text { Programme } \\
\text { Kompas TV }\end{array}$ \\
\hline
\end{tabular}

\begin{tabular}{|l|l|l|}
\hline Distributed Via & by Zaim Saidi, the & \\
RT Video & initiator of the & \\
Video Kompas & muamalah market & \\
TV about more & network in Depok, & \\
expensive & was distributed to the & \\
commodity & local RT chairman. & \\
prices, it is & \\
difficult to & \\
return [32] & & \\
\hline PBNU & The interview with & "Aiman" \\
Chairman Asks & KH Marsudi Syuhud & Programme \\
Police to & asked the police to be & Kompas TV \\
Carefully & careful handling the & \\
Investigate & case of the muamalah & \\
Muamalah & market network & \\
Market Cases & managed by Zaim & \\
that Transaction & Saidi because printing & \\
Using Dinar and & money and using the & \\
Dirmah [33] & money for transactions & \\
& is a legal matter and & \\
& mixed with sharia & \\
muamalah issues. & \\
\hline New Facts Of & Interview with Sari & "Aiman" \\
Dinar-Dirham & and Nisa, a trader in & Programme \\
Use Transaction & Pasar Muamalah & Kompas TV \\
in Muamalah & Depok, that & \\
Market of & transactions using & \\
Depok: Soaring & dinar coins and Zaim & \\
Prices, Difficult & Saidi dirhams have the & \\
to Get Back & opportunity to catapult & \\
Video Kompas & commodity prices and & \\
TV about more & are difficult to get & \\
expensive & back. \\
commodity & & \\
prices, it is & & \\
difficult to be & & \\
able to return & & \\
[34] & & \\
\hline
\end{tabular}

\section{2) Causal Interpretation.}

In the overall news about the Depok Muamalah Market by Kompas.com, Zaim Saidi is positioned as the perpetrator who is the cause of the problem, namely the lawbreaker. Meanwhile, the police are positioned as law enforcers, not rulers who hinder the expression of Islamic religious identity. Zaim Saidi's position as a lawbreaker can be identified by the narrative developed by Kompas.com as follows: first, Zaim Saidi is positioned as the brain behind the unlicensed Depok Muamalah Market. The operation of a market should have a permit from the government. By not having an operational permit, the Depok Muamalah Market is illegal. A further implication of the illegal market category is that activities at Muamalah Market in Depok are also illegal activities.

Second, apart from being the founder, Zaim Saidi was stated to have played a role in the Depok Muamalah Market as a market manager and wakala master. The following is the statement of the Head of the Public Information Division of the Public Relations Division of the Police Kombes (Pol) Ahmad Ramadhan: "At the same time as the manager and as the main wakala, which is a place to exchange Rupiah into dinars or dirhams which are used as a medium of exchange in the muamalah market." 
Third, Depok Muamalah Market using dinars and dirhams in buying and selling transactions is positioned as violating the law. The use of dinars and dirhams instead of rupiah violates the law on the currency. Kompas.com includes a statement from the Executive Director, Head of the Bank Indonesia (BI) Communications Department, Erwin Haryono, as follows: "Along with indications of the use of payment instruments other than rupiah in the community, BI confirms that rupiah is the only legal tender in the community. The Unitary State of The Republic of Indonesia (Negara Kesatuan Republik IndonesiaNKRI)." The use of dinars and dirhams is considered to violate the provisions of Article 33 of Law Number 7 of 2011 concerning Currency. The article stipulates that the only legal tender in Indonesia is the rupiah. Anyone who refuses to pay in Rupiah currency shall be punished with imprisonment for a maximum of one year and a fine of Rp. 200,000,000.00.

Furthermore, Kompas.com presented the BI Director's statement as follows: "BI is committed to continuing to encourage the movement to love and care for the rupiah together with the relevant authorities and all components of society as a symbol of state sovereignty."

Making dinar and dirham coins is also considered a violation of the law. The police used Article 9 of Law Number 1 of 1946 on Criminal Law to arrest Zaim Saidi. Article 9 of Law 1/1946 states that anyone who makes objects such as currency or banknotes to be used as legal tender is punished with a maximum imprisonment of 15 years.

Kompas.com also includes a statement from the Chairman of the Nahdlatul Ulama (PBNU) Executive Board, Marsudi Syuhud, who asked the police to be careful in handling the case of the muamalah market network managed by Zaim Saidi. The following is Shuhud's statement: "This is a legal issue that is printing money and using the money for transactions, then it is mixed up with this sharia muamalah issue." Syuhud also stated that: "The issue that is subject to law is not the muamalah, not the muamalah market. Those who are subject to the law are for printing money and using it, this is something that is not allowed. Everything else is fine." Although Kompas.com contains a statement requesting that Zaim Saidi's status does not immediately become a suspect in violating the law, the discourse is drowned out by the discourse that Zaim Saidi is a suspect in violating the law.

\section{3) Moral Evaluation.}

The issue of the Depok Muamalah Market is assessed by Kompas.com as an issue of nationalism. Nationalism is a variant of political identity. Nationalism in this case is law enforcement for the sovereignty of the rupiah. The Muamalah Market in Depok is considered unlawful because it does not have a permit and uses dinars and dirhams instead of rupiah.
The moral value of violating the law delegitimizes the existence of the Depok Muamalah Market. It also legitimizes all police actions to close the Depok Muamalah Market and convict the initiator of the Depok Muamalah Market, Zaim Saidi.

\section{4) Treatment Recommendations.}

The solution to the problem regarding the development of the Depok Muamalah Market issue is that those who violate the law need to be punished. This was done by arresting Zaim Saidi and detaining him. Zaimsaidi also faces imprisonment and a fine.

TABLE II. FRAME OF MUAMALAH MARKET OF DEPOK NEWS

\begin{tabular}{|l|l|}
\hline \multicolumn{1}{|c|}{$\begin{array}{c}\text { Problem } \\
\text { Identification }\end{array}$} & \multicolumn{1}{c|}{ Violation of the law } \\
\hline $\begin{array}{l}\text { Causal } \\
\text { Interpretation }\end{array}$ & $\begin{array}{l}\text { Zaim Saidi is the causative factor of the } \\
\text { problem, the police enforce the law of } \\
\text { Pasar Muamalah Depok does not have a } \\
\text { permit and uses dinars and dirhams instead } \\
\text { of rupiah, breaking the law. }\end{array}$ \\
\hline Moral Evaluation & $\begin{array}{l}\text { Nasionalisme dalam konteks penegakan } \\
\text { hukum untuk kedaulatan rupiah }\end{array}$ \\
\hline $\begin{array}{l}\text { Treatment } \\
\text { Recommendation }\end{array}$ & $\begin{array}{l}\text { Lawbreakers need to be criminally } \\
\text { prosecuted Muamalah Market of Depok } \\
\text { closed }\end{array}$ \\
\hline \multicolumn{2}{|c}{$\quad$ a. By Kompas.com }
\end{tabular}

\section{B. Republika.co.id's frame about Muamalah Market} in Depok

Republika.co.id is part of the Republika Daily Newspaper, which has been operating since August 17, 1995 (https://www.republika.co.id/page/about). Harian Republika is a newspaper founded by the Muslim community in 1992. The establishment of Harian Republika was supported by the Indonesian Muslim Intellectuals Association (ICMI), one of the most influential Muslim organizations at that time.

As with Kompas.com's framing, Republika.co.id's framing is also seen from the aspect of inclusion of issues and highlighting aspects of the issues selected. Republika.co.id has been reporting on the Depok Muamalah Market since 2016, namely December 28, 2016, as shown in Table 3, Table 4, and Table 5. The following reports are from January 29, 2021, to February 4, 2012, 29 times. The duration is quite long and the frequency of reporting is quite frequent for an issue in online media.

\section{1) Problem identification.}

Republika.co.id identified the Depok Muamalah Market as an issue regarding Islamic teachings. There are two reasons why the frame of Islamic teachings was attached to Republika.co.id in reporting on the Depok Muamalah Market. First, the title of the news is contained in Table 3 which confirms that the Depok Muamalah Market is to run the economy according to the sunnah of the apostle. The news headline "Dinar and Dirham in Islamic Teachings" also led to public opinion that the use of dinars and dirhams is an Islamic teaching. In addition, the news headline "Want to Eliminate Riba? Here's How" emphasized that the use 
of dinars and dirhams is an attempt to eliminate usury. Riba is one of the teachings of Islam. Second, the consequence of framing Islamic religious identity is the news sources interviewed, namely the initiator of the Depok Muamalah Market, Zaim Saidi, and the traders at the Depok Muamalah Market. Many news sources are also in favor of the Depok Muamalah Market.

TABLE III. NEWS ABOUT MUAmalah MARKET OF DEPOK BY REPUBLIKA.CO.ID

\begin{tabular}{|c|c|c|}
\hline Title of News & Content of News & Source of News \\
\hline $\begin{array}{l}\text { Muamalah } \\
\text { Market, Run the } \\
\text { Economy } \\
\text { According to } \\
\text { Sunah Rasul [35] }\end{array}$ & $\begin{array}{l}\text { Interview with the } \\
\text { founder of Pasar } \\
\text { Muamalah Depok. } \\
\text { Muamalah Market } \\
\text { is an economic } \\
\text { practice following } \\
\text { the Sunna of the } \\
\text { Apostle. }\end{array}$ & $\begin{array}{l}\text { Zaim Saidi } \\
\text { (founder of } \\
\text { Muamalah Market } \\
\text { of Depok) }\end{array}$ \\
\hline $\begin{array}{l}\text { In Picture: } \\
\text { Muamalah Market } \\
\text { in Depok, Doing } \\
\text { Business } \\
\text { According to } \\
\text { Sunah Rasulullah } \\
\text { [35] }\end{array}$ & $\begin{array}{l}\text { Photographs of } \\
\text { merchants show } \\
\text { dinars and dirhams. } \\
\text { Socialize dinars } \\
\text { and dirhams as a } \\
\text { stable medium of } \\
\text { exchange and have } \\
\text { the same value } \\
\text { everywhere so that } \\
\text { there are no } \\
\text { problems in the } \\
\text { exchange rate. }\end{array}$ & $\begin{array}{l}\text { Traders at } \\
\text { Muamalah Market } \\
\text { of Depok. }\end{array}$ \\
\hline $\begin{array}{l}\text { Want to Lose } \\
\text { Riba? Here's How } \\
{[36]}\end{array}$ & $\begin{array}{l}\text { The use of dinars } \\
\text { and dirhams is to } \\
\text { eliminate riba. The } \\
\text { use of dirhams is } \\
\text { easier than rupiah } \\
\text { and its value is } \\
\text { more certain. }\end{array}$ & $\begin{array}{l}\text { Zaim Saidi } \\
\text { (founder of } \\
\text { Muamalah Market } \\
\text { of Depok) } \\
\text { Lukman Nurudin } \\
\text { (trader) }\end{array}$ \\
\hline $\begin{array}{l}\text { There is } \\
\text { Muamalah Market } \\
\text { of Depok, Dinar \& } \\
\text { Dirham Use } \\
\text { Transaction [37] }\end{array}$ & $\begin{array}{l}\text { Muamalah Market } \\
\text { conducts buying } \\
\text { and selling } \\
\text { transactions } \\
\text { following the } \\
\text { teachings of } \\
\text { ancient Prophets. }\end{array}$ & Suarabogor.id \\
\hline $\begin{array}{l}\text { Lurah: Muamalah } \\
\text { Market in Depok } \\
\text { does not have an } \\
\text { environmental } \\
\text { permit [38] }\end{array}$ & $\begin{array}{l}\text { The interview with } \\
\text { Lurah Tanah Baru } \\
\text { that Muamalah } \\
\text { Market of Depok } \\
\text { does not have a } \\
\text { permit, was held in } \\
\text { front of the } \\
\text { shophouse. } \\
\text { Interview with } \\
\text { Zaim Saidi that } \\
\text { Muamalah Market } \\
\text { of Depok aims for } \\
\text { alms, zakat, trade } \\
\text { so that the } \\
\text { economy can } \\
\text { continue to move; } \\
\text { clean trade, with no } \\
\text { rent or usury. }\end{array}$ & $\begin{array}{l}\text { Zakky Fauzan } \\
\text { (Lurah Tanah } \\
\text { Baru) Zaim Saidi } \\
\text { (founder of } \\
\text { Muamalah Market } \\
\text { of Depok) }\end{array}$ \\
\hline $\begin{array}{l}\text { Polri Benarkan } \\
\text { Catch Muamalah } \\
\text { Market Initiator } \\
\text { Video Republika } \\
\text { TV: Do not easily } \\
\text { associate }\end{array}$ & $\begin{array}{l}\text { Interview with } \\
\text { Brigadier General } \\
\text { Rusdi Hartono that } \\
\text { Zaim Saidi was } \\
\text { arrested. }\end{array}$ & $\begin{array}{l}\text { Brig. Gen. Rusdi } \\
\text { Hartono (Karo } \\
\text { Penmas Public } \\
\text { Relations Division } \\
\text { of Police) }\end{array}$ \\
\hline
\end{tabular}

\begin{tabular}{|c|c|c|}
\hline $\begin{array}{l}\text { muamalah with } \\
\text { the caliphate [39] }\end{array}$ & & \\
\hline $\begin{array}{l}\text { Zaim Saidi } \\
\text { Arrested, } \\
\text { Wasekjen MUI: } \\
\text { Should Be Built } \\
\text { Video Republika } \\
\text { TV: Do not easily } \\
\text { associate } \\
\text { muamalah with } \\
\text { the caliphate [40] }\end{array}$ & $\begin{array}{l}\text { Interview with } \\
\text { Ikhsan Abdullah } \\
\text { that the practice of } \\
\text { muamalah is true } \\
\text { because muamalah } \\
\text { is good by sharia } \\
\text { means. Muamalah } \\
\text { syariah is also } \\
\text { being encouraged } \\
\text { by the government } \\
\text { through various } \\
\text { instruments } \\
\text { including } \\
\text { strengthening } \\
\text { sharia economy. } \\
\text { The practice of } \\
\text { transactions using } \\
\text { dinars and dirhams } \\
\text { is wrong. The } \\
\text { obligation of the } \\
\text { Police to conduct } \\
\text { coaching to the } \\
\text { community, } \\
\text { muamalah market } \\
\text { continues to run } \\
\text { using rupiah. }\end{array}$ & $\begin{array}{l}\text { Ikhsan Abdullah } \\
\text { \{Deputy Secretary } \\
\text { General of the } \\
\text { Indonesian Ulema } \\
\text { Council } \\
\text { (Wasekjen MUI) } \\
\text { for Law and } \\
\text { Human Rights }\end{array}$ \\
\hline $\begin{array}{l}\text { Zaim Saidi, Who } \\
\text { Was Recently } \\
\text { Arrested by Police } \\
\text { [41] }\end{array}$ & $\begin{array}{l}\text { The Police press } \\
\text { conference that } \\
\text { Zaim Saidi, } \\
\text { founder of Pasar } \\
\text { Muamalah Depok } \\
\text { was arrested by the } \\
\text { Directorate of } \\
\text { Special Economic } \\
\text { Crimes or } \\
\text { Dirtipideksus Polri } \\
\text { on Tuesday, } \\
\text { February } 2 \text {, } 2021 \text {. } \\
\text { Zaim is suspected } \\
\text { by article } 9 \text { of Law } \\
\text { No. } 1 \text { of } 1946 \text { on } \\
\text { criminal law and } \\
\text { article } 33 \text { of Law } \\
\text { Number } 7 \text { of } 2011 \\
\text { on the currency. } \\
\text { With the threat of a } \\
\text { sentence of } 1 \text { year } \\
\text { in prison and a fine } \\
\text { of } 200 \text { million } \\
\text { rupiah }\end{array}$ & $\begin{array}{l}\text { Kombes (Pol) } \\
\text { Ahmad Ramadhan } \\
\text { (Head of Public } \\
\text { Information } \\
\text { Division of Public } \\
\text { Relations Division } \\
\text { of Police) }\end{array}$ \\
\hline $\begin{array}{l}\text { Zaim Saidi's } \\
\text { Arrest Begins in } \\
\text { Viral Video [42] }\end{array}$ & $\begin{array}{l}\text { The police press } \\
\text { conference that } \\
\text { Zaim Saidi, } \\
\text { founder of Pasar } \\
\text { Muamalah Depok, } \\
\text { was arrested } \\
\text { because Pasar } \\
\text { Muamalah Depok } \\
\text { uses a medium of } \\
\text { exchange other } \\
\text { than rupiah, } \\
\text { namely dinar and } \\
\text { dirham, as a means } \\
\text { of buying and } \\
\text { selling transactions. } \\
\text { Zaim Saidi acts as } \\
\text { initiator and } \\
\text { provider of } \\
\text { Muamalah Market, }\end{array}$ & $\begin{array}{l}\text { Kombes (Pol) } \\
\text { Ahmad Ramadhan } \\
\text { (Head of Public } \\
\text { Information } \\
\text { Division of Public } \\
\text { Relations Division } \\
\text { of Police) }\end{array}$ \\
\hline
\end{tabular}




\begin{tabular}{|c|c|c|c|c|c|}
\hline & $\begin{array}{l}\text { as well as manager } \\
\text { and as } \\
\text { 'Wakalainduk'. }\end{array}$ & & & \multirow{2}{*}{$\begin{array}{l}\text { Muamalah Market } \\
\text { of Depok for } \\
\text { Sharia transactions, } \\
\text { the mechanism has } \\
\text { taken must follow } \\
\text { the rules. It is not } \\
\text { wrong if the police } \\
\text { arrest Zaim Saidi. }\end{array}$} & \\
\hline \multirow[t]{4}{*}{$\begin{array}{l}\text { Zaim Saidi, PBNU } \\
\text { arrest: Police must } \\
\text { be careful [43] }\end{array}$} & \multirow{4}{*}{$\begin{array}{l}\text { Interview with } \\
\text { K.H. Marsudi } \\
\text { Syuhud that the } \\
\text { police must be } \\
\text { careful in handling } \\
\text { Muamalah Market } \\
\text { of Depok. The } \\
\text { police must make it } \\
\text { clear to the public } \\
\text { that there are } \\
\text { violations by Zaim } \\
\text { Saidi. Muamalah } \\
\text { did not break the } \\
\text { law, instead was } \\
\text { pushed by the } \\
\text { government. Do } \\
\text { not let the police } \\
\text { instead become an } \\
\text { obstacle to the } \\
\text { sharia economy } \\
\text { driven by the } \\
\text { government. Sharia } \\
\text { economy already } \\
\text { has rules and has } \\
\text { organizations, } \\
\text { namely the Islamic } \\
\text { Economic } \\
\text { Community } \\
\text { (MES), the } \\
\text { Association of } \\
\text { Sharia Economists } \\
\text { (IAEI), even } \\
\text { economic } \\
\text { organizations in } \\
\text { which there is a } \\
\text { President and Vice } \\
\text { President. }\end{array}$} & \multirow{4}{*}{$\begin{array}{l}\text { KH Marsudi } \\
\text { Syuhud } \\
\text { \{Chairman of The } \\
\text { General Manager } \\
\text { of Nahdlatul } \\
\text { Ulama (PBNU)\} }\end{array}$} & & & \\
\hline & & & $\begin{array}{l}\text { Police: Zaim Saidi } \\
\text { Message Dinar- } \\
\text { Dirham to PT } \\
\text { Antam [47] }\end{array}$ & $\begin{array}{l}\text { Zaim Saidi Police } \\
\text { press conference } \\
\text { ordered dinar and } \\
\text { dirham money to } \\
\text { PT. Aneka } \\
\text { Tambang (Antam) } \\
\text { Tbk. }\end{array}$ & $\begin{array}{l}\text { Kombes (Pol) } \\
\text { Ahmad Ramadhan } \\
\text { (Head of Public } \\
\text { Information } \\
\text { Division of Public } \\
\text { Relations Division } \\
\text { of Police) }\end{array}$ \\
\hline & & & $\begin{array}{l}\text { Vice President: } \\
\text { Dinar-Dirham } \\
\text { Transaction } \\
\text { Damaged National } \\
\text { Finances [48] }\end{array}$ & $\begin{array}{l}\text { "Mata Najwa" } \\
\text { television shows } \\
\text { that Islamic } \\
\text { financial } \\
\text { mechanisms } \\
\text { outside the rules } \\
\text { and agreements } \\
\text { will damage } \\
\text { Indonesia's national } \\
\text { economic and } \\
\text { financial system. }\end{array}$ & $\begin{array}{l}\text { Ma'ruf Amin } \\
\text { (Vice President of } \\
\text { The Republic of } \\
\text { Indonesia) }\end{array}$ \\
\hline & & & $\begin{array}{l}\text { Viral Dinar } \\
\text { Dirham, What Do } \\
\text { Sharia Glasses } \\
\text { Mean? Republika } \\
\text { TV Video: Don't } \\
\text { easily associate } \\
\text { muamalah } \text { with } \\
\text { the caliphate [49] }\end{array}$ & $\begin{array}{l}\text { Interview with } \\
\text { Irfan Syauqi Beik } \\
\text { that the use of dinar } \\
\text { dirham as an } \\
\text { academic activity } \\
\text { certainly does not } \\
\text { violate the rules. } \\
\text { But transactions as } \\
\text { currency are not } \\
\text { justified because } \\
\text { the official money } \\
\text { is money regulated } \\
\text { by law and the } \\
\text { official money in }\end{array}$ & $\begin{array}{l}\text { Irfan Syauqi Beik } \\
\text { (IPB University } \\
\text { Sharia Economics } \\
\text { Observer) }\end{array}$ \\
\hline \multirow{2}{*}{$\begin{array}{l}\text { Police: Zaim Saidi } \\
\text { takes } 2.5 \text { percent } \\
\text { profit from Dinar- } \\
\text { Dirham [44] }\end{array}$} & \multirow{2}{*}{$\begin{array}{l}\text { The police press } \\
\text { conference that } \\
\text { Zaim Saidi, took } \\
\text { advantage of } 2.5 \\
\text { percent of each } \\
\text { dinar and dirham } \\
\text { coin exchange. }\end{array}$} & \multirow{2}{*}{$\begin{array}{l}\text { Kombes (Pol) } \\
\text { Ahmad Ramadhan } \\
\text { (Head of Public } \\
\text { Information } \\
\text { Division of Public } \\
\text { Relations Division } \\
\text { of Police) } \\
\end{array}$} & & $\begin{array}{l}\text { Indonesia is the } \\
\text { rupiah. }\end{array}$ & \\
\hline & & & \multirow{2}{*}{$\begin{array}{l}\text { Polri: Pasar } \\
\text { Muamalah Depok } \\
\text { Operating Since } \\
\text { 2014 Video } \\
\text { Republika TV: Do } \\
\text { not easily } \\
\text { associate } \\
\text { muamalah with } \\
\text { khilafah [50] }\end{array}$} & \multirow{2}{*}{$\begin{array}{l}\text { The police press } \\
\text { conference that } \\
\text { Muamalah Market } \\
\text { in Depok, West } \\
\text { Java, has been } \\
\text { operating since } \\
2014\end{array}$} & \multirow{2}{*}{$\begin{array}{l}\text { Kombes (Pol) } \\
\text { Ahmad Ramadhan } \\
\text { (Head of Public } \\
\text { Information } \\
\text { Division of Public } \\
\text { Relations Division } \\
\text { of Police) }\end{array}$} \\
\hline \multirow[t]{3}{*}{$\begin{array}{l}\text { Zaim Saidi Arrest: } \\
\text { Police Must Be } \\
\text { Extra Careful [45] }\end{array}$} & \multirow{3}{*}{$\begin{array}{l}\text { Interview with Jeje } \\
\text { Zaenudin that the } \\
\text { police must also be } \\
\text { extra careful and } \\
\text { not be led by } \\
\text { opinions formed by } \\
\text { certain groups, } \\
\text { especially if framed } \\
\text { is political and } \\
\text { needs to be } \\
\text { clarified and } \\
\text { studied first from } \\
\text { various aspects. }\end{array}$} & \multirow{3}{*}{$\begin{array}{l}\text { Jeje Zaenudin } \\
\text { \{Vice Chairman } \\
\text { of the Central } \\
\text { Leadership (PP) } \\
\text { of the Islamic } \\
\text { Union (Persis)\} }\end{array}$} & & & \\
\hline & & & $\begin{array}{l}\text { Muamalah Market } \\
\text { Case, Vice } \\
\text { President: Our } \\
\text { Transaction Tool } \\
\text { Rupiah [51] }\end{array}$ & $\begin{array}{l}\text { The transaction } \\
\text { tool following } \\
\text { Indonesian } \\
\text { financial rules is } \\
\text { the rupiah. }\end{array}$ & $\begin{array}{l}\text { Ma'ruf Amin } \\
\text { (Vice President of } \\
\text { The Republic of } \\
\text { Indonesia) }\end{array}$ \\
\hline & & & \multirow[t]{2}{*}{$\begin{array}{l}\text { Dinar and Dirham } \\
\text { in Islamic } \\
\text { Teachings [52] }\end{array}$} & \multirow{2}{*}{$\begin{array}{l}\text { In Islamic } \\
\text { jurisprudent, gold } \\
\text { and silver coins are } \\
\text { known as essential } \\
\text { (real) mediums of } \\
\text { exchange while } \\
\text { copper or bronze } \\
\text { money is known as } \\
\text { fulus and is a } \\
\text { medium of } \\
\text { exchange by } \\
\text { agreement. Islam } \\
\text { prohibits the } \\
\text { accumulation of } \\
\text { money and makes }\end{array}$} & \multirow{2}{*}{$\begin{array}{l}\text { Article } \\
\text { knepublishing.com } \\
\text { with the title "The } \\
\text { Role of Gold } \\
\text { Dinar And Silver } \\
\text { Dirham User } \\
\text { Entrepreneurship } \\
\text { Community in } \\
\text { Dinar-Dirham } \\
\text { Replacement } \\
\text { Equipment As a } \\
\text { Medium of } \\
\text { Exchange." }\end{array}$} \\
\hline $\begin{array}{l}\text { Vice President: } \\
\text { Dinar-Dirham } \\
\text { Usage Deviates } \\
\text { Republika TV } \\
\text { Video: Don't } \\
\text { easily associate } \\
\text { muamalah } \text { with } \\
\text { the caliphate [46] }\end{array}$ & $\begin{array}{l}\text { Interview with } \\
\text { Ma'ruf Amin that } \\
\text { the use of gold } \\
\text { money or dinar } \\
\text { dirham is not } \\
\text { following existing } \\
\text { rules and } \\
\text { regulations. } \\
\text { in the country or } \\
\text { deviant. Although } \\
\text { the purpose of }\end{array}$ & $\begin{array}{l}\text { Ma'ruf Amin } \\
\text { (Vice President of } \\
\text { The Republic of } \\
\text { Indonesia) }\end{array}$ & & & \\
\hline
\end{tabular}




\begin{tabular}{|c|c|c|}
\hline & $\begin{array}{l}\text { money a } \\
\text { commodity } \\
\text { because hoarding } \\
\text { money means } \\
\text { slowing the } \\
\text { turnover of money. } \\
\text { Islam prohibits } \\
\text { usury and rejects } \\
\text { all kinds of } \\
\text { artificial } \\
\text { transactions, such } \\
\text { as those in the } \\
\text { money market or } \\
\text { capital markets. } \\
\text { Gold money is } \\
\text { universal and } \\
\text { acceptable to all } \\
\text { parties because the } \\
\text { material is gold and } \\
\text { is relatively more } \\
\text { difficult to } \\
\text { counterfeit. Gold } \\
\text { money has certain } \\
\text { colors, levels, and } \\
\text { strengths that } \\
\text { cannot be made } \\
\text { from other metals. } \\
\text { Gold money can be } \\
\text { used as a savings } \\
\text { tool whose value is } \\
\text { relatively more } \\
\text { stable. In Islamic } \\
\text { economics, the } \\
\text { function of money } \\
\text { is only recognized } \\
\text { as a medium of } \\
\text { exchange and a } \\
\text { unit of calculation. } \\
\text { Money itself does } \\
\text { not provide } \\
\text { usefulness, but the } \\
\text { function of money } \\
\text { that provides } \\
\text { usability. } \\
\end{array}$ & \\
\hline $\begin{array}{l}\text { How Does the } \\
\text { Dinar-Dirham } \\
\text { Transaction } \\
\text { Impact the } \\
\text { Economy? [53] }\end{array}$ & $\begin{array}{l}\text { The practice that is } \\
\text { being widely } \\
\text { carried out in } \\
\text { Muamalah Market } \\
\text { of Depok urgently } \\
\text { needs further } \\
\text { discussion and } \\
\text { discussion. Its } \\
\text { effect on the } \\
\text { economy, } \\
\text { according to Irfan, } \\
\text { is insignificant } \\
\text { because of its } \\
\text { function to the } \\
\text { medium of } \\
\text { exchange, not as } \\
\text { money. Its effect } \\
\text { on the value of } \\
\text { gold only, if it is } \\
\text { widely used then } \\
\text { many people ask } \\
\text { for gold, the price } \\
\text { of gold will rise. }\end{array}$ & $\begin{array}{l}\text { Irfan Syauqi Beik } \\
\text { (IPB University } \\
\text { Sharia Economics } \\
\text { Observer) }\end{array}$ \\
\hline $\begin{array}{l}\text { Dinar Dirham } \\
\text { Case in Glasses of } \\
\text { Currency Law } \\
\text { [54] }\end{array}$ & $\begin{array}{l}\text { In the Currency } \\
\text { Law, Zaim said, } \\
\text { there is no use of } \\
\text { other currencies, }\end{array}$ & $\begin{array}{l}\text { Zaim Saidi } \\
\text { (founder of Pasar } \\
\text { Muamalah } \\
\text { Depok) Head of }\end{array}$ \\
\hline
\end{tabular}

\begin{tabular}{|c|c|c|}
\hline & $\begin{array}{l}\text { such as the dollar } \\
\text { and yen, while } \\
\text { dinar-dirhams fall } \\
\text { into the category of } \\
\text { jewelry. Second, } \\
\text { because dinars and } \\
\text { dirhams are jewelry } \\
\text { (assets). Zaim } \\
\text { stated, the principle } \\
\text { of the transaction } \\
\text { was not buying and } \\
\text { selling in the form } \\
\text { of currency, but } \\
\text { barter based on } \\
\text { agreements. For } \\
\text { Zaim Saidi, barter } \\
\text { did not violate the } \\
\text { agreement. He } \\
\text { gave comparisons } \\
\text { such as the use of } \\
\text { coins in some } \\
\text { children's game } \\
\text { locations. Every } \\
\text { transaction that has } \\
\text { a payment purpose } \\
\text { made in the } \\
\text { territory of NKRI } \\
\text { must use rupiah. }\end{array}$ & $\begin{array}{l}\text { BI } \\
\text { Communications } \\
\text { Department, } \\
\text { Erwin Haryono }\end{array}$ \\
\hline $\begin{array}{l}\text { Vice President: } \\
\text { Muamalah Dinar } \\
\text { Dinar Dirham } \\
\text { Market is not } \\
\text { Following the } \\
\text { Rules [55] }\end{array}$ & $\begin{array}{l}\text { The use of gold } \\
\text { money or dirham is } \\
\text { not following the } \\
\text { rules and } \\
\text { regulations. }\end{array}$ & $\begin{array}{l}\text { Ma'ruf Amin } \\
\text { (Vice President of } \\
\text { The Republic of } \\
\text { Indonesia) }\end{array}$ \\
\hline $\begin{array}{l}\text { How are Dinar- } \\
\text { Dirham } \\
\text { Transactions } \\
\text { Allowed? } \\
\text { Republika TV } \\
\text { Video: Don't } \\
\text { easily associate } \\
\text { muamalah } \text { with } \\
\text { the caliphate [56] }\end{array}$ & $\begin{array}{l}\text { The use of dinar- } \\
\text { dirham in barter } \\
\text { practices is still } \\
\text { allowed in } \\
\text { Indonesia. }\end{array}$ & $\begin{array}{l}\text { Irfan Syauqi Beik } \\
\text { (IPB University } \\
\text { Sharia Economics } \\
\text { Observer) }\end{array}$ \\
\hline $\begin{array}{l}\text { Than Dinar } \\
\text { Dirham, } \\
\text { Cryptocurrencies } \\
\text { Rated More } \\
\text { Dangerous Video } \\
\text { Republika TV: } \\
\text { Don't easily } \\
\text { associate } \\
\text { muamalah with } \\
\text { Khilafah [57] }\end{array}$ & $\begin{array}{l}\text { Interview with } \\
\text { Irfan Syauqi Beik } \\
\text { that this } \\
\text { cryptocurrency is } \\
\text { more dangerous } \\
\text { and can have a } \\
\text { systemic effect if it } \\
\text { is used because } \\
\text { cryptocurrencies } \\
\text { are currently } \\
\text { unstable, even } \\
\text { though they need to } \\
\text { be stable. }\end{array}$ & $\begin{array}{l}\text { Irfan Syauqi Beik } \\
\text { (IPB University } \\
\text { Sharia Economics } \\
\text { Observer) }\end{array}$ \\
\hline $\begin{array}{l}\text { Zaim Saidi } \\
\text { Ditangkap, } \\
\text { Pengamat: } \\
\text { Berlebihan [58] }\end{array}$ & $\begin{array}{l}\text { Zaim Saidi was } \\
\text { arrested and } \\
\text { processed by law } \\
\text { with suspicions that } \\
\text { I think are still } \\
\text { debatable and } \\
\text { excessive," Ficker } \\
\text { said in a written } \\
\text { statement on } \\
\text { Thursday (4/2). } \\
\text { Fickar explained, } \\
\text { the spirit of } \\
\text { community is not } \\
\text { only aspired and } \\
\text { loved by the }\end{array}$ & $\begin{array}{l}\text { Abdul Fickar } \\
\text { Hajar (Criminal } \\
\text { Law Expert from } \\
\text { Trisaksi } \\
\text { University) }\end{array}$ \\
\hline
\end{tabular}




\begin{tabular}{|l|l|}
\hline & Muslim \\
community, as a & \\
"fair platform". & This is precisely \\
the choice of many & people who are not \\
limited to Muslim & communities only. \\
Muamalah market & is also a slice of the \\
Sharia economy. & \\
\hline
\end{tabular}

2) Causal Interpretation.

In the whole news about the Depok Muamalah Market by Kompas.com, Zaim Saidi is positioned as the actor who is the cause of the problem. Zaim Saidi is positioned as the brain behind Depok's unlicensed Muamalah Market. Depok Muamalah Market uses dinars and dirhams in buying and selling transactions, not using rupiah. The use of dinars and dirhams violates the law on the currency. Making dinar and dirham coins that resemble

\section{3) Moral Evaluation.}

Republika.co.id places the Depok Muamalah Market as a manifestation of Islamic teachings. The muamalah market is the implementation of Islamic teachings and is the implementation of the sunnah of the apostle. Depok Muamalah Market is part of the sharia economy that is driven by the government. To encourage the sharia economy in Indonesia, the government established sharia banking, sharia economic councils, and allowed sharia shares to operate in the capital market. Zaim Saidi is judged as an implementer of Islamic teachings, not a lawbreaker.

\section{4) Treatment Recommendations.}

As a consequence of the framing that the Depok Muamalah Market is the implementation of Islamic teachings, the Muamalah Market needs to be continued. Zaim Saidi's arrest is considered debatable and excessive.

TABLE IV. THE FRAME OF MUAMALAH MARKET OF DEPOK NEWS

\begin{tabular}{|l|l|}
\hline \multicolumn{1}{|c|}{$\begin{array}{c}\text { Problem } \\
\text { Identification }\end{array}$} & \multicolumn{1}{|c|}{ Teachings of Islam } \\
\hline Causal Interpretation & $\begin{array}{l}\text { The police caused The Muamalah } \\
\text { Market of Depok to be closed and Zaim } \\
\text { Saidi detained and threatened with } \\
\text { criminal damage. }\end{array}$ \\
\hline Moral Evaluation & $\begin{array}{l}\text { Muamalah market is the } \\
\text { implementation of Islamic teachings, } \\
\text { part of sharia economy that is } \\
\text { encouraged by the government zaim } \\
\text { saidi is the implementer of Islamic } \\
\text { teachings. }\end{array}$ \\
\hline $\begin{array}{l}\text { Treatment } \\
\text { Recomendation }\end{array}$ & $\begin{array}{l}\text { Muamalah market needs to continue, } \\
\text { zaim saidi arrest is debatable and } \\
\text { excessive }\end{array}$ \\
\hline
\end{tabular}

b. By Republika.co.id

\section{Comparison of Kompas.com and Republika.co.id Framing on Depok Muamalah Market}

The discussions in sections $\mathrm{A}$ and $\mathrm{B}$ show how the same event is defined and interpreted differently. Different definitions cause an event to change fundamentally. The definitions of the Depok Muamalah Market by Kompas.com and Republika.co.id is different, as listed in Table 5. Kompas.com defines the Depok Muamalah Market as a violation of the law, especially related to the current law. If explored further, violations of the law regarding currency will be related to the sovereignty of the rupiah in the Republic of Indonesia. Because it is related to rupiah sovereignty, it is closely related to Indonesian nationalism. Nationalism is a variation of political identity. In contrast to Kompas.com, Republika.co.id assessed that the Depok Muamalah Market was not a violation of the law, but a practice of Islamic teachings. Because it is part of the teachings, it has the same value as the practice of other Islamic teachings. In the economic context, Depok Muamalah Market is also a part of sharia economic practice. Sharia economic development is one of the Indonesian government's programs.

Different definitions and meanings will have an impact on who is considered the causative factor and who is the victim. Kompas.com considers Zaim Saidi as an actor who violates the law and Indonesian nationalism as a victim. The Muamalah Market in Depok, which uses dinars and dirhams, threatens the sovereignty of the rupiah in Indonesia. This means distracting Indonesian nationalism. Meanwhile, Republika.co.id placed the police as the cause of the problem which resulted in the closure of Depok's Muamalah Market and Zaim Saidi being arrested, detained, and threatened with a fine and imprisonment.

The next implication is how each of them recommends solving the Depok Muamalah Market issue. Kompas.com recommends that Depok Muamalah Market be closed for violating the law and Zaim Saidi be punished. Meanwhile, Republika.co.id, because it considers Depok Muamalah Market a practice of Islamic teachings, needs to be allowed to continue operating.

TABLE V. COMPARISON OF MUAMALAH MARKET OF DEPOK NEWS FRAME

\begin{tabular}{|l|l|l|}
\hline \multicolumn{1}{|c|}{ Element } & \multicolumn{1}{|c|}{ Kompas.com } & \multicolumn{1}{c|}{ Republika.co.id } \\
\hline Frame & $\begin{array}{l}\text { Political identity: } \\
\text { Nationalism }\end{array}$ & $\begin{array}{l}\text { Religious identity: } \\
\text { Islam }\end{array}$ \\
\hline $\begin{array}{l}\text { Problem } \\
\text { Identificati } \\
\text { on }\end{array}$ & Violation of the law & Teachings of Islam \\
\hline $\begin{array}{l}\text { Causal } \\
\text { Interpretati } \\
\text { on }\end{array}$ & $\begin{array}{l}\text { Zaim Saidi is the } \\
\text { causative factor of } \\
\text { the problem, the } \\
\text { police enforce the } \\
\text { law of Pasar } \\
\text { Muamalah Depok } \\
\text { does not have a }\end{array}$ & $\begin{array}{l}\text { The police caused The } \\
\text { Muamalah Market of } \\
\text { Zaim Saidi was } \\
\text { detained and } \\
\text { threatened with } \\
\text { criminal damage. }\end{array}$ \\
\hline \multicolumn{2}{|l}{} \\
\hline
\end{tabular}




\begin{tabular}{|l|l|l|}
\hline & $\begin{array}{l}\text { permit and uses } \\
\text { dinars and dirhams } \\
\text { instead of rupiah, } \\
\text { breaking the law. }\end{array}$ & \\
\hline $\begin{array}{l}\text { Moral } \\
\text { Evaluation }\end{array}$ & $\begin{array}{l}\text { Nasionalisme dalam } \\
\text { konteks penegakan } \\
\text { hukum untuk } \\
\text { kedaulatan rupiah }\end{array}$ & $\begin{array}{l}\text { Muamalah } \text { market is } \\
\text { the implementation of } \\
\text { Islamic teachings, part } \\
\text { of sharia economy that } \\
\text { is encouraged by the } \\
\text { government zaim saidi } \\
\text { is the implementer of } \\
\text { Islamic teachings. }\end{array}$ \\
\hline $\begin{array}{l}\text { Treatment } \\
\text { Recommen } \\
\text { dation }\end{array}$ & $\begin{array}{l}\text { Lawbreakers need to } \\
\text { be criminally } \\
\text { prosecuted } \\
\text { Muamalah } \text { Market } \\
\text { of Depok closed }\end{array}$ & $\begin{array}{l}\text { Muamalah } \text { market } \\
\text { needs to continue, } \\
\text { zaim saidi arrest is } \\
\text { debatable and } \\
\text { excessive }\end{array}$ \\
\hline
\end{tabular}

Although the reports by Kompas.com and Republika.co.id differ, both of them have carried out the function of the press in a democracy, namely surveillance, education, platform, publicity, and advocacy [6]. In carrying out the surveillance function, both of them have provided information to citizens about the Depok Muamalah Market. In carrying out the education function, Kompas.com teaches the meaning of nationalism while Republika.co.id teaches the meaning of Islamic teachings on the Depok Muamalah Market issue. In carrying out their publicity function, they both proclaim and are watchdogs on the work of the police and Bank Indonesia. In carrying out the function of advocacy on the political views of the community through the principle of openness, both of them have advocated for citizens with the ideology of nationalism and followers of Islam.

Different framing will lead to different public opinions. A plurality of views in democracy is something commonplace. Democracy is also understood in terms of freedom of speech, expression, and association [7]. In this sense, every citizen has the right to express opinions, express thoughts, feelings, and desires. Every citizen also has the right to form or join certain communities and organizations. Freedom also includes expressing one's identity, whether it is based on social, political, or cultural discourse. It is also normal for residents to establish Depok Muamalah Market as an expression of their religion, and it is also normal for other residents, with the ideology of nationalism, to criticize Depok Muamalah Market. Likewise, in terms of reporting on the Depok Muamalah Market, it is normal in a democracy if the reporting is different. Different reporting is also fair in democracy because of the principles of civic equality, equal freedom, and basic opportunity [8].

Different reports by the press on the same issue are also commonplace in political communication. Reporting by the media is not always what it is. Reporting by the press is colored by the identity or ideology of the media and the people who manage the media. Ideology, political attitudes, editorial policies of a media also determine the use of political symbols, message packaging, and giving place to an issue or political power in the news. This can be seen that Kompas.com is colored by the ideology of nationalism, while Republika.co.id is influenced by the ideology of Islam. The press has become a media as well as an arena for the contestation of various interests and powers [9]. Public opinion and what discourse will dominate will depend on many factors. What is certain is that discourse that dominates or even hegemons is what wins the contest.

\section{CONCLUSION}

The Muamalah Market in Depok is an important phenomenon in the study of identity politics. Likewise the news about it. The phenomenon of Pasar Muamalah Depok gives a different impression and meaning because it is reported with different frames by Kompas.com and Republika.co.id. Furthermore, different news frames give rise to different public opinions.

The two online media studied included the issue of the Depok Muamalah Market, but in a different frame. Kompas.com tends to frame it with the ideology of nationalism and that means political identity. While Republika.co.id tends to frame Depok Muamalah Market with Islam and that means Islamic religious identity. However, the issue of the Depok Muamalah Market both maintains the ideology promoted by its founders. Kompas.com with the ideology of nationalism and Republika.co.id with the ideology of Islam. In a democracy, plurality of discourses caused by differences in news framing is a natural thing. It shows that there is democracy in Indonesia. The press has the freedom to express their opinion according to the framing chosen in reporting on the Depok Muamalah Market. The different framing in the coverage of the Depok Muamalah Market also shows that the press is an arena for discourse contestation.

\section{ACKNOWLEDGMENT}

This research was funded by the University of Lampung's DIPA BLU at the initiative of the University of Lampung Research and Community Service Institute (LPPM Unila). Thanks to LPPM Unila.

\section{REFERENCES}

[1] Michael Kenny, The Politics of Identity, Cambridge: Polity Press, 2004, pp.

[2] Arie Setyaningrum. "Memetakan Lokasi bagi 'Politik Identitas' dalam Wacana Politik Poskolonial." Jurnal Mandatory. IRE. Yogyakarta. Edisi 2/Tahun 2/2005. Pp. 1334.

[3] Dan Nimmo, Political Communication and Public Opinion in America. Santa Monica, California: Goodyear Publishing, 1978.

[4] Dennis McQuail Sven Windhal, Communication Models: for the Study of Mass Communication. New York: Longman, 1996 ,

[5] Ibnu Hamad, "Konstruksi realitas politik dalam media massa (studi pesan politik dalam media cetak pada masa pemilu 
1999)" Makara, sosial humaniora, vol. 8, no. 1, pp. 21-33, April 2004.

[6] Brian McNair, An Introduction To Political Communication, London: Routlegdge, 1999, pp. 2-15.

[7] David Beetham, Democracy, Oxford: One world Publications, 2005, pp. 1-4

[8] Amy Gutman, Identity in Democracy, Princenton and Oxford: Princenton University Press, 2003, pp. 26-30

[9] Nyarwi, "Paradoks Media Sebagai Pilar Keempat Demokrasi" Jurnal Sosial Politik, Volume 12, Nomor 2, pp. 121-256, November 2008.

[10] Eriyanto, Analisis Framing, Konstruksi, Ideologi, dan Politik Media, LkiS Edisi Khusus Komunitas, 2018, pp. 219-252.

[11] https://megapolitan.kompas.com/read/2021/01/28/1352 0151/kabar-viral-pasar-muamalah-di-depok-transaksipakai-dirham-dan-dinar-ini?page=all\#page3. Accesed on February, 25, 2021, 08.05 am.

[12] https://megapolitan.kompas.com/read/2021/01/28/1438 5351/pasar-muamalah-di-depok-yang-terimatransaksi-dinar-dan-dirham-tak-punya. Accesed on July, 02, 2021, 08.00 am.

[13] https://money.kompas.com/read/2021/01/28/16420212 6/viral-transaksi-pakai-dinar-dan-dirham-bi-cumarupiah-alat-pembayaran-yang-sah?page=all\#page 2 . Accesed on July, 02, 2021, 08.05 am.

[14] https://megapolitan.kompas.com/read/2021/01/28/2114 2901/viral-transaksi-pakai-dinar-dan-dirham-di-depokpenjelasan-lurah-dan. Accesed on July, 02, 2021, 08.10 am.

[15] https://megapolitan.kompas.com/read/2021/01/29/0647 2271/populer-iabodetabek-viral-transaksimenggunakan-dinar-dan-dirham-di-depok. Accesed on July, 02, 2021, 08.20 am.

[16] https://megapolitan.kompas.com/read/2021/01/29/0936 1641/kabar-viral-transaksi-pakai-dinar-dan-dirham-didepok-apa-sanksinya. Accesed on July, 02, 2021, 08.30 am.

[17] https://megapolitan.kompas.com/read/2021/01/29/1433 5941/kata-pedagang-selain-koin-dinar-dan-dirhampasar-muamalah-depok-terima?page=all\#page 2 . Accesed on July, 02, 2021, 08.40 am.

[18] https://megapolitan.kompas.com/read/2021/01/30/0848 4511/viral-transaksi-pakai-dinar-dirham-di-pasarmuamalah-depok-dan-tanggapan?page=all\#page 2 Accesed on July, 02, 2021, 08.50 am.

[19] https://megapolitan.kompas.com/read/2021/01/31/2128 3131/ternyata-dinar-dan-dirham-pernah-ada-di-pasarmuamalah-cipondoh-ini?page=all\#page2. Accesed on July, 03, 2021, 08.20 am.

[20] https://nasional.kompas.com/read/2021/02/03/1046140 1/bareskrim-polri-tangkap-pendiri-pasar-muamalahdepok-zaim-saidi. Accesed on July, 03, 2021, 08.30 am.

[21] https://nasional.kompas.com/read/2021/02/03/1132378 1/ditangkap-polisi-pendiri-pasar-muamalah-depokzaim-saidi-berstatus-tersangka. Accesed on July, 03 , 2021, $08.40 \mathrm{am}$.

[22] https://megapolitan.kompas.com/read/2021/02/03/1222 0691/polisi-tangkap-pendiri-pasar-muamalah-depokyang-perkenalkan-dirham-dan?page=all\#page3. Accesed on July, 03, 2021, 08.50 am.

[23] https://megapolitan.kompas.com/read/2021/02/03/1331 3191/dugaan-pelanggaran-uu-mata-uang-dalam-kasuspasar-muamalah-depok. Accesed on July, 03, 2021, $09.00 \mathrm{am}$.

[24] https://nasional.kompas.com/read/2021/02/03/1503450 1/tersangka-pendiri-pasar-muamalah-zaim-saiditerancam-1-tahun-penjara. Accesed on July, 03, 2021, $09.10 \mathrm{am}$.
[25] https://nasional.kompas.com/read/2021/02/03/1514044 1/mabes-polri-pasar-muamalah-depok-beroperasisejak-2014. Accesed on July, 03, 2021, 09.20 am.

[26] https://megapolitan.kompas.com/read/2021/02/03/1518 3981/kronologi-ditangkapnya-zaim-saidi-berawal-daritransaksi-dinar-dirham-di?page=all\#page2. Accesed on February, 25, 2021, $08.00 \mathrm{am}$.

[27] https://nasional.kompas.com/read/2021/02/03/1543162 1/ini-pasal-pidana-yang-jerat-zaim-saidi-pendiri-pasarmuamalah-depok. Accesed on July, 03, 2021, 09.30 am.

[28] https://nasional.kompas.com/read/2021/02/04/0928494 1/fakta-fakta-penangkapan-zaim-saidi-pendiri-pasarmuamalah -depok?page=all. Accesed on July, 03, 2021, $09.40 \mathrm{am}$.

[29] https://megapolitan.kompas.com/read/2021/02/09/0513 3741/transaksi-dengan-dirham-harga-2-kg-telur-setararp-73500-di-pasar. Accesed on July, 03, 2021, 09.50 am.

[30] https://megapolitan.kompas.com/read/2021/02/09/0534 0641/zaim-saidi-ditahan-polisi-dalam-kasus-pasarmuamalah-di-depok-ini?page=all\#page2. Accesed on July, 03, 2021, 10.00 am

[31] https://megapolitan.kompas.com/read/2021/02/09/0554 $1131 /$ koin-dinar-dirham-di-pasar-muamalah-depokdisebut-dibagikan-via-rt?page $=$ all\#page 3 . Accesed on July, 03, 2021, 10.10 am

[32] https://megapolitan.kompas.com/read/2021/02/09/0805 3871/ketua-pbnu-minta-polisi-hati-hati-usut-kasuspasar-muamalah-yang. Accesed on July, 03, 2021, $10.20 \mathrm{am}$.

[33] https://megapolitan.kompas.com/read/2021/02/09/0941 4161/fakta-anyar-transaksi-pakai-dinar-dirham-dipasar-muamalah-depok-harga?page $=$ all. Accesed on July, 03, 2021, 10.30 am.

[34] https://www.republika.co.id/berita/dunia-islam/islamnusantara/16/12/18/oidlxl301-pasar-muamalah-jalankanekonomi-sesuai-sunah-rasul. Accesed on July, 10, 2021, $05.30 \mathrm{am}$.

[35] https://www.republika.co.id/berita/oidmer283/pasarmuamalah-di-depok-berbisnis-sesuai-sunah-rasulullah. Accesed on July, 10, 2021, 05.35 am.

[36] https://www.republika.co.id/berita/dunia-islam/islamnusantara/16/12/18/oidmjl301-ingin-hilangkan-riba-beginicaranya. Accesed on July, 10, 2021, 05.40 am.

[37] https://www.republika.co.id/berita/qnoj7e10018000/ad a-pasar-muamalah-depok-transaksi-pakai-dinardirham. Accesed on February, 25, 2021, 08.10 am.

[38] https://www.republika.co.id/berita/qnot9x484/lurahpasar-muamalah-di-depok-tak-miliki-izin-lingkungan Accesed on July, 10, 2021, 05.50 am.

[39] https://www.republika.co.id/berita/qnxr2j428/polribenarkan-tangkap-penggagas-pasar-muamalah. Accesed on February, 25, 2021, 08.15 am. Accesed on July, 10, 2021, $06.00 \mathrm{am}$.

[40] https://www.republika.co.id/berita/qny64x320/zaimsaidi-ditangkap-wasekjen-mui-sebaiknya-dibina. Accesed on July, 15, 2021, $05.00 \mathrm{am}$.

[41] https://www.republika.co.id/berita/qny7ih328/zaimsaidi-yang-baru-ditangkap-sekarang-oleh-polisi. Accesed on July, 15, 2021, $05.10 \mathrm{am}$.

[42] https://www.republika.co.id/berita/qny87c328/penangk apan-zaim-saidi-bermula-dari-video-viral. Accesed on July, 15, 2021, 05.15 am

[43] https://www.republika.co.id/berita/qny8h9320/penangk apan-zaim-saidi-pbnu-polisi-harus-hatihati. Accesed on July, 15, 2021, 05.20 am 
[44] https://www.republika.co.id/berita/qny9aa409/polisizaim-saidi-ambil-untung-25-persen-dari-dinardirham. Accesed on July, 15, 2021, $05.30 \mathrm{am}$.

[45] https://www.republika.co.id/berita/qnyhjp396/penangk apan-zaim-saidi-persis-polisi-harus-ekstra-cermat. Accesed on July, 15, 2021, $05.35 \mathrm{am}$.

[46] https://www.republika.co.id/berita/qnz3zy428/waprespenggunaan-dinardirham-menyimpang. Accesed on July, 15, 2021, 05.40 am.

[47] https://repjabar.republika.co.id/berita/qnz5qc428/polrizaim-saidi-pesan-dinardirham-ke-pt-antam. Accesed on July, 15, 2021, 05.50 am.

[48] https://repjabar.republika.co.id/berita/qnz6qd428/wapr es-transaksi-dinardirham-rusak-keuangan-nasional. Accesed on July, 15, 2021, $05.55 \mathrm{am}$.

[49] https://www.republika.co.id/berita/qnz931383/viraldinar-dirham-bagaimana-menurut-kacamatasyariah?utm_source=dable. Accesed on July, 15, 2021, $10.00 \mathrm{am}$.

[50] https://www.republika.co.id/berita/qnz7g4428/polripasar-muamalah-depok-beroperasi-sejak-2014. Accesed on July, 15, 2021, 10.10 am.

[51] https://www.republika.co.id/berita/qnzjqv487/kasuspasar-muamalah-wapres-alat-transaksi-kita-rupiah. Accesed on July, 15, 2021, $10.20 \mathrm{am}$.
[52] https://www.republika.co.id/berita/qnzkik385/dinardan-dirham-dalam-ajaran-islam. Accesed on July, 15, $2021,10.30 \mathrm{am}$

[53] https://www.republika.co.id/berita/qnzkik385/dinardan-dirham-dalam-ajaran-islam-part1. Accesed on July, 15, 2021, $10.40 \mathrm{am}$.

[54] https://www.republika.co.id/berita/qnzkik385/dinardan-dirham-dalam-ajaran-islam-part2. Accesed on July, 15, 2021, $10.45 \mathrm{am}$.

[55] https://www.republika.co.id/berita/qnzjqv487/kasuspasar-muamalah-wapres-alat-transaksi-kita-rupiah. Accesed on July, 15, 2021, 10.50 am.

[56] https://www.republika.co.id/berita/qnzl11383/bagaima na-dampak-transaksi-dinardirham-terhadap-ekonomi. Accesed on July, 15, 2021, $11.00 \mathrm{am}$.

[57] https://www.republika.co.id/berita/qnzl11383/bagaima na-dampak-transaksi-dinardirham-terhadap-ekonomipart1. Accesed on July, 15, 2021, 11.10 am.

[58] https://www.republika.co.id/berita/qnzp7w318/kasusdinar-dirham-dalam-kacamata-uu-mata-uang. Accesed on July, 15, 2021, $11.20 \mathrm{am}$. 